\title{
IMPROVEMENT OF THE CONNECTIONS IN TIMBER STRUCTURES IN THEORY AND PRACTICE
}

\author{
Dragoslav Stojić ${ }^{1}$ \\ Radovan Cvetković ${ }^{2}$ \\ Stefan Conić ${ }^{3}$ \\ Nemanja Marković ${ }^{4}$
}

UDK: 624.011.1.07

DOI: $10.14415 / k o n f e r e n c i j a G F S 2019.006$

Summary: Connections between timber structural elements are realized, usually with different steel jointing devices, which are installed in combination with specially shaped steel elements in accordance with certain theoretical settings and calculations. In the case of solid timber $(C)$ or glued laminated timber $(G L)$ constructions of large spans, there is a important consumption of steel for making connections between the elements of the primary and secondary structures. In this paper we give a brief overview of the development and improvement of modern models and methods of calculating connections in timber structures, through examples of original design solutions that have achieved the savings of connecting means in relation to the classic way of forming connections between timber elements. These solutions are followed by the need for high quality of glued laminated timber beams production and precision finishing.

Keywords: timber, construction details, connections, fasteners, development

\section{INTRODUCTION}

Timber structures of large-scale objects and dimensions, special or ordinary architectural forms, are very often distinguished by original and innovative design of connections between main and secondary structural elements. Special and compulsory attention of such constructions should be dedicated to providing spatial stability and methods of connecting all structural elements to a functional whole. Practical solutions involve the use of various steel coupling devices, most commonly connecting rods and steel profiled elements for connection of elements of primary and secondary timber structures. The steel profiled elements follow the dimensions of the cross-sections of the main structural

\footnotetext{
${ }^{1}$ Prof. Dr Dragoslav Stojić, The Faculty of Civil Engineering and Architecture, University of Niš, Aleksandra Medvedeva 14, Niš, Serbia, e - mail: dragoslav.stojic@gmail.com

2 Ass. Dr Radovan Cvetković, The Faculty of Civil Engineering and Architecture, University of Niš, Aleksandra Medvedeva 14, Nišs, Serbia, e - mail: radovancvetkovic @yahoo.com

${ }^{3}$ Stefan Conić, M.Sc. C. Eng. PhD student, Scholar of the Ministry, The Faculty of Civil Engineering and Architecture, University of Niš, Aleksandra Medvedeva 14, Niš, Serbia, e - mail: stefanv1989@yahoo.com

${ }^{4}$ Ass. Nemanja Marković, C. Eng. PhD student, The Faculty of Civil Engineering and Architecture, University of Niš, Aleksandra Medvedeva 14, Niš, Serbia, e - mail: nemanjamarkovic85@gmail.com
} 
elements and are dimensions are determined to the boundary load, but also according to the needs of shaping the connection itself and the optimal criteria for the installation of coupling means. The thickness of the bonding steel plates for the construction of supports, specially designed steel elements for connecting beams and columns, rafters and beams, of course in the load function, may be up to $30 \mathrm{~mm}$. In the overall cost of construction cost, depending on the global design, steel profiled elements necessary for the connection of timber structural elements participate with a certain part. Based on our design experience, based on sports and industrial halls projects up to $2000 \mathrm{~m}^{2}$ of the covered area, in comparison with the total cost of the construction cost, the steel, participates with a part which may be up to $20 \%$.

In some of our projects of recent date, in order to reduce the participation of steel fittings in the connections of timber construction elements, we have created special connection solutions based on:

- $\quad$ special "carpentry" design of finishing parts of timber construction elements,

- application of fasteners, in particular self-rotating screws of a certain diameter,

- optimal utilization of normal and shear stresses in the support zones, zones of connection of the timber elements of the secondary and primary structures,

- methods of coupling type timber-timber with minimal use of constructional connecting means,

- change of the static system of the elements of the secondary roof structure: the static model of the simple beam is replaced by the model of the continuous beam.

- the spatial stability provided by the elements of the full cross-section, the corresponding stiffness and the timber as the basic material.

In the continuation of the work, we have provided the elements of the calculation of fasteners according to Johansen's theory, with the intent to specifically emphasize the importance and application of self-compacting screws in efforts to reduce the use of classic steel fittings in timber constructions, the overview of the original details of the connections from our design practice and the table overview of the quantity of steel fittings in conventional solutions in relation to our solutions.

\section{DESIGN OF FASTENERS ACCORDING TO JOHANSEN'S THEORY}

This part of work deals with design methods and procedures for determination of load bearing capacity bar-shaped connectors (fasteners), very often used as element connecting element in timber structures. Here will be given needed equations and rules for calculation load bearing capacity of dowel and bolts (fasteners) used for connecting main and secondary girders of a structure.

The procedure will be exposed and explained according to the new-fashioned methods collected as set of Euro-norms in Eurocode 5. 
Contemporary achievements in civil engineering 23-24. April 2019. Subotica, SERBIA

Therefore, the load bearing capacity of connections with dowel type fasteners like bolts, dowels and nails determined according to Johansen theory, depends on the geometry of connection, the bending resistance of the dowel and the embedding strength of the timber.

For the bending resistance of the dowel Johansen assumed the elastic moment capacity of the dowel's cross-section.

The design equations in Eurocode 5, derived from Johansen's work are based on a rigid plastic behaviour of the dowel under bending moments and the timber under embedding stresses and take into account the plastic moment capacity of the dowel.

Three different possible failure modes are possible for timber-timber connections in double shear (figure 1.)
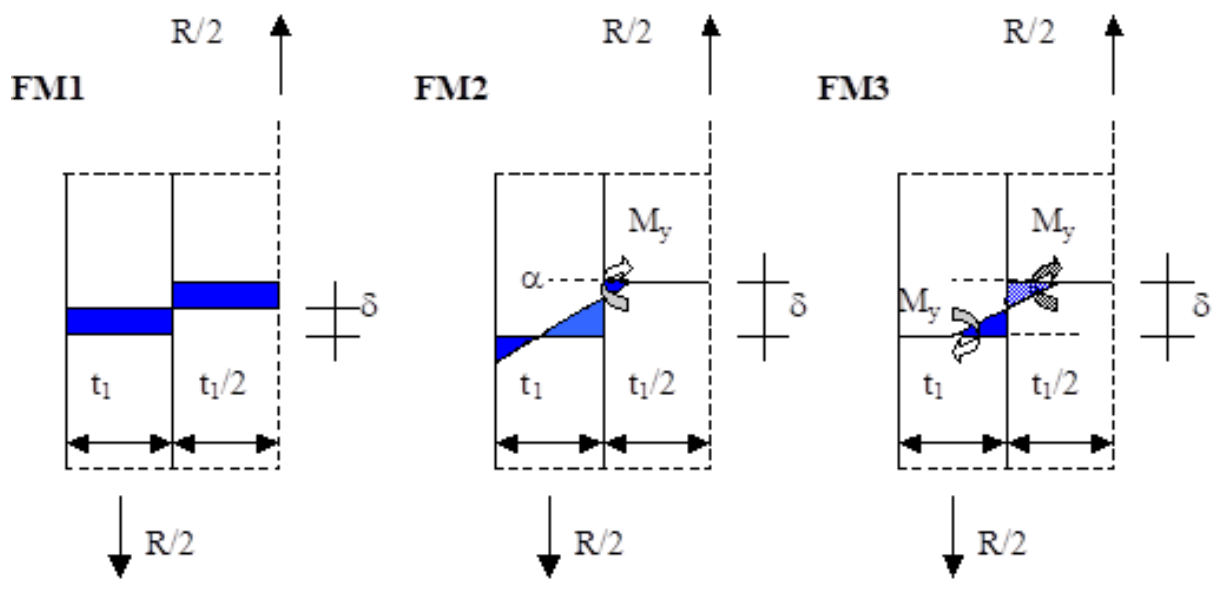

Figure 1. Failure modes (FM) for timber-timber connections in double shear

Failure mode 1 (FM 1) corresponds to the embedding failure of the middle or side member, respectively. In failure modes 2 and 3, apart from the embedding strength of the timber, the bending capacity of the fastener is reached. Failure modes 2 and 3 of dowels loaded in double shear correspond to identical failure modes of dowels loaded in single shear.

According to EN 409 the yield moment of a fasteners is determined at a bending angle of $45^{\circ}$ for such a large bending angle, the whole cross-section of the fastener is assumed to be under plastic strain. For bending angles below $45^{\circ}$ only the outer areas of the crosssection of a fastener are deformed plastically.

For the load-bearing capacity of a fasteners is determined according to EN 26891, the connection strength is defined as the maximum load before a deformation of $\delta=15 \mathrm{~mm}$ parallel to the load direction reached. The large number of connections tested show that in most cases failure modes 2 and 3 occurred and the bending angles were significantly below $\alpha=45^{\circ}$.

It means that the plastic moment capacity of the dowel was not attained in the connection, namely, dowel's cross-section were only partially plasticised. Further, it means lower bending capacity and consequently, lower connection strength values. Therefore, if a deformation limit of $15 \mathrm{~mm}$ is assumed for connection the effective bending capacity 
Савремена достигнућа у грађевинарству 23-24. април 2019. Суботица, СРБИЈА

depends on the yield strength of the fastener material, the fastener diameter and the shape of the moment-angle diagram of the fastener shown on the figure 2.

Moment-angle-diagram evaluated on the base bending test different fasteners. Since the shape of $M(\alpha)$ is very similar for different fastener diameters $d$, mean curve $M(\alpha)$ was determined and approximated by an exponential function of $\alpha$ expressed by equations:

$$
M(\alpha)=(0,866+0,00295 \alpha) \cdot\left(1-e^{\left(\frac{-0,248 \alpha}{0,866}\right)}\right)
$$

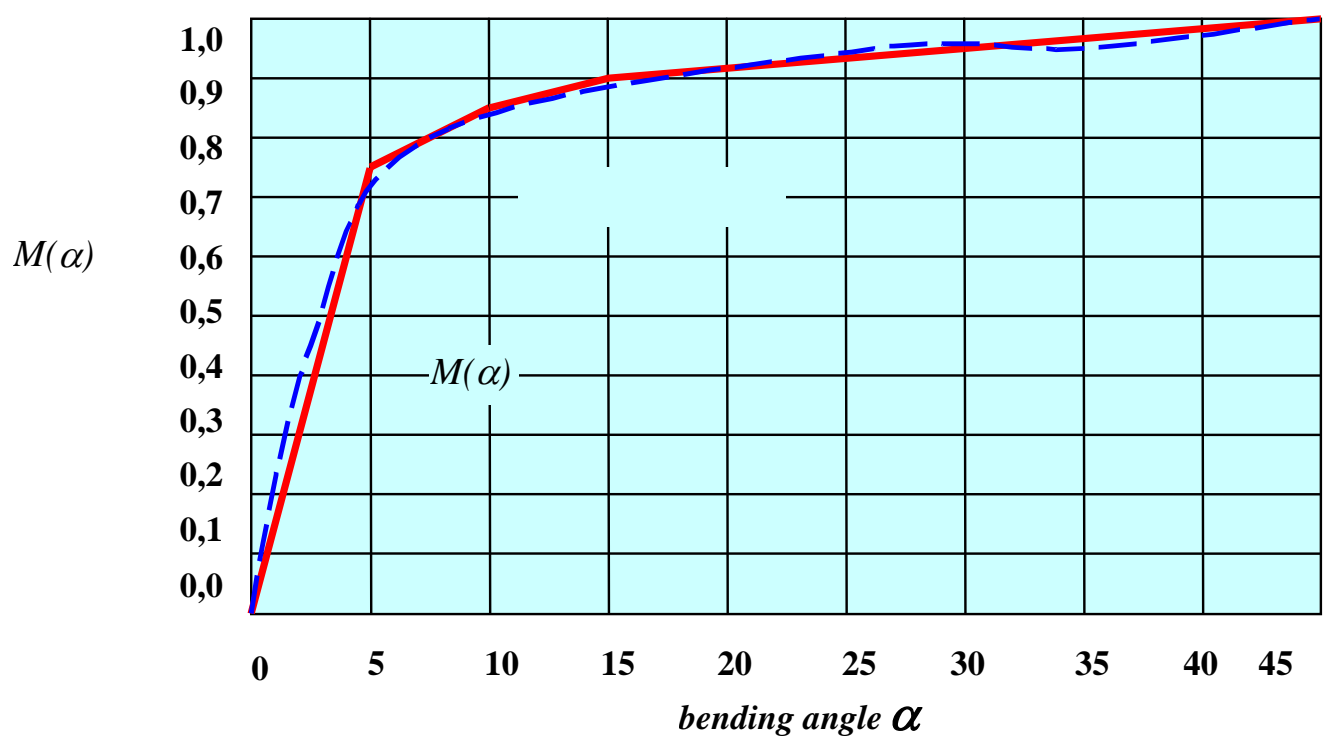

Figure 2. Mean normalised moment-angle-diagram of dowel-type fasteners and approximation

The parameters influencing $\alpha(\mathrm{d})$ depend on the fastener material and the embedding strength. For bolts, nails and dowels in predrilled holes the embedding strength is determined according to EN 383 as:

$$
f_{h, k}=0,082(1-0,01 d) \rho_{k}
$$

The yield strength in bending $f_{y}$ according to Eurocode 5 is $80 \%$ of the tensile strength $f_{u, k}$ of the steel grade used.

The equation for the yield moment for bolts and dowels given in Eurocode 5 too, has shape:

$$
M_{y, k}=0,3 f_{u, k} \cdot d^{2,6}
$$

The yields moment of nails with circular cross section with a minimum wire tensile strength of $600 \mathrm{~N} / \mathrm{mm}^{2}$ according to Eurocode 5 is: 
Contemporary achievements in civil engineering 23-24. April 2019. Subotica, SERBIA

$$
M_{y, k}=180 f_{u, k} \cdot d^{2,6}
$$

For the different types of fastener the function $\alpha(\mathrm{d})$ can be determined resulting in minimum values of the bending angle $\alpha$ with governing parameters which are conservatively chosen and resulting as maximum values for the steel tensile strength and minimum values for the characteristic density.

For connections with bolts or dowels, the tensile strength $f_{y, k}$ is chosen as $1000 \mathrm{~N} / \mathrm{mm}^{2}$ and the characteristic density $\rho_{k}$ as $350 \mathrm{~kg} / \mathrm{m}^{3}$

Inserting these values in equation 3.4.1 results in a relation between the normalised moment and the fastener diameter $d$.

Multiplying $M(\alpha(d))$ and the yield moment according to equation 3.4.7, we can get expression for the effective bending capacity of bolts and dowels for a deformation $\delta=15 \mathrm{~mm}$ as fallow:

$$
M_{y, k}=0,27 f_{u, k} \cdot d^{2,6}
$$

where:

$f_{u, k} \quad$ fastener tensile strength in $\mathrm{N} / \mathrm{mm}^{2}$,

$d \quad$ fastener diameter in $\mathrm{mm}$.

Equation 3 for the bending capacity of bolts or dowels takes into account the decreasing bending angle with increasing fastener diameter.

On the basis of Johansen's ultimate load equations the load-bearing capacities of single and double shear timber-to-timber as well as steel-to-timber connections are derived. It is assumed that the fastener and the timber are ideal rigid-plastic materials.

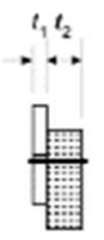

a

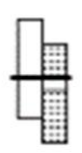

b

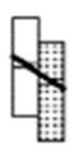

C

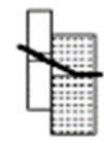

d

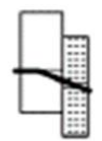

e

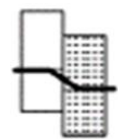

f
(1)

(2)

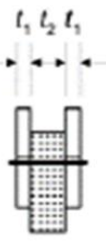

g

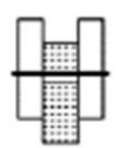

h

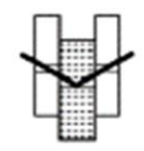

j

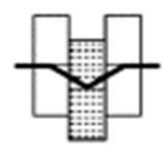

k

Figure 3. Single shear and double shear connections 
Савремена достигнућа у грађевинарству 23-24. април 2019. Суботица, СРБИЈА

For design value of load bearing capacity of the fastener per shear plane in single shear connection type timber-timber loaded perpendicular in relation to axe direction of the fastener, it is necessary to take the lowest value calculated from fallowing expressions:

$$
\mathrm{R}_{\mathrm{d}}=\min \left\{\begin{array}{l}
\mathrm{f}_{\mathrm{h}, 1, \mathrm{~d}} \mathrm{t}_{1} \mathrm{~d} \\
\mathrm{f}_{\mathrm{h}, 2, \mathrm{~d}} \mathrm{t}_{2} \mathrm{~d} \\
\frac{\mathrm{f}_{\mathrm{h}, 1, \mathrm{~d}} \mathrm{t}_{1} \mathrm{~d}}{1+\beta}\left[\sqrt{\beta+2 \beta^{2}\left[1+\frac{\mathrm{t}_{2}}{\left.\mathrm{t}_{1}+\left(\frac{\mathrm{t}_{2}}{\mathrm{t}_{1}}\right)^{2}\right]+\beta^{3}\left(\frac{\mathrm{t}_{2}}{\mathrm{t}_{1}}\right)^{2}}-\beta\left(1+\frac{\mathrm{t}_{2}}{\mathrm{t}_{1}}\right)\right]}\right. \\
1,1 \frac{\mathrm{f}_{\mathrm{h}, 1, \mathrm{~d}} \mathrm{t}_{1} \mathrm{~d}}{2+\beta}\left[\sqrt{2 \beta(1+\beta)+\frac{4 \beta(2+\beta) \mathrm{M}_{\mathrm{y}, \mathrm{d}}}{\mathrm{f}_{\mathrm{h}, 1, \mathrm{~d}} \mathrm{dt}_{1}^{2}}}-\beta\right] \\
1,1 \frac{\mathrm{f}_{\mathrm{h}, 1, \mathrm{~d}} \mathrm{t} \mathrm{d}}{1+2 \beta}\left[\sqrt{2 \beta^{2}(1+\beta)+\frac{4 \beta(1+2 \beta) \mathrm{M}_{\mathrm{y}, \mathrm{d}}}{\mathrm{f}_{\mathrm{h}, 1, \mathrm{~d}} \mathrm{dt}_{2}^{2}}}-\beta\right] \\
1,1 \sqrt{\frac{2 \beta}{1+\beta}} \sqrt{2 \mathrm{M}_{\mathrm{y}, \mathrm{d}} \mathrm{f}_{\mathrm{h}, 1, \mathrm{~d}} \mathrm{~d}}
\end{array}\right]
$$

For design value of load bearing capacity of the fastener per shear plane in double shear connection type timber-timber loaded perpendicular in relation to axe direction of the fastener, it is necessary to take the lowest value calculated from fallowing expressions:

$$
\mathrm{R}_{\mathrm{d}}=\min \left\{\begin{array}{l}
\mathrm{f}_{\mathrm{h}, 1, \mathrm{~d}} \mathrm{t}_{1} \mathrm{~d} \\
0,5 \mathrm{f}_{\mathrm{h}, 2, \mathrm{~d}} \mathrm{t}_{2} \mathrm{~d} \\
1,1 \frac{\mathrm{f}_{\mathrm{h}, 1, \mathrm{~d}} \mathrm{t}_{1} \mathrm{~d}}{2+\beta}\left[\sqrt{2 \beta(1+\beta)+\frac{4 \beta(2+\beta) \mathrm{M}_{\mathrm{y}, \mathrm{d}}}{\mathrm{f}_{\mathrm{h}, 1, \mathrm{~d}} \mathrm{dt}_{1}^{2}}}-\beta\right] \\
1,1 \sqrt{\frac{2 \beta}{1+\beta}} \sqrt{2 \mathrm{M}_{\mathrm{y}, \mathrm{d}} \mathrm{f}_{\mathrm{h}, 1, \mathrm{~d}} \mathrm{~d}}
\end{array}\right.
$$

The following notation is used:

$t_{1}$ and $t_{2}$

timber thickness,

$f_{h, 1, d}, f_{h, 2, d} \quad$ embedding strength corresponding to $t_{1}$ or $t_{2}$, respectively,

$\beta \quad$ relation $f_{h, 2, d} / f_{h, 1, d}$,

d fastener diameter,

$M_{y, d} \quad$ fastener yield moment.

Design values of the embedded strengths $f_{h, l, d}$ and $f_{h, 2, d}$ need to calculate according to fallowing equations: 
Contemporary achievements in civil engineering 23-24. April 2019. Subotica, SERBIA

$$
f_{h, 1, d}=k_{\text {mod,1 }} \cdot f_{h, 1, k} / \gamma_{m}, \quad f_{h, 2, d}=k_{\text {mod }, 2} \cdot f_{h, 2, k} / \gamma_{m}
$$

Design value of a fastener yield moment needs to calculate according to fallowing expression:

$$
M_{y, d}=M_{y, k} / \gamma_{m}
$$

For design value of load bearing capacity of the fastener per shear plane in single shear steel-to-timber connection, with thickness of steel plate, $t \leq 0,5 d$ loaded perpendicular in relation to axe direction of the fastener, it is necessary to take the lowest value calculated from fallowing expressions:

$$
R_{d}=\min \left\{\begin{array}{l}
(\sqrt{2}-1) f_{h, 1, d} t_{1} d \\
1,1 \sqrt{2 M_{y, d} f_{h, 1, d} d}
\end{array}\right.
$$

For the thickness of steel plate, $t>d$, to use next expressions in the same sense:

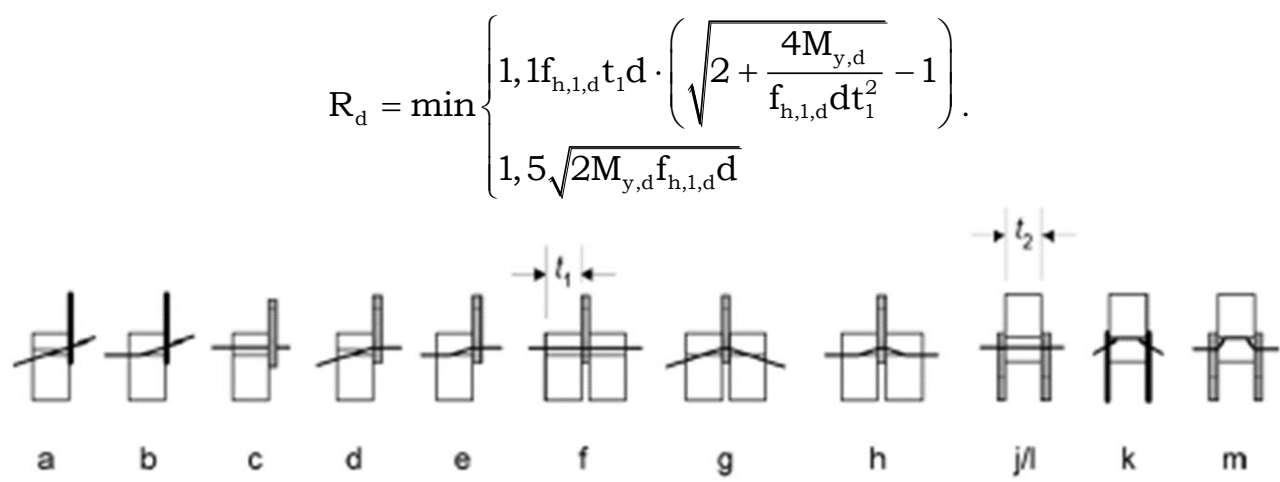

Figure 4. Single shear and double shear steel plate-to-timber connections

For design value of load bearing capacity of the fastener per shear plane in double shear steel-to-timber connection, where the thick steel plate is between timber elements, loaded perpendicular in relation to axe direction of the fastener, it is necessary to take the lowest value calculated from fallowing expressions:

$$
R_{d}=\min \left\{\begin{array}{l}
1,1 f_{h, 1, d} t_{1} d \\
1,1 f_{h, 1, d} t_{1} d\left(\sqrt{2+\frac{4 M_{y, d}}{f_{h, 1, d} \mathrm{dt}_{1}^{2}}}-1\right) \\
1,5 \sqrt{2 M_{y, d} f_{h, 1, d} d}
\end{array}\right)
$$


Савремена достигнућа у грађевинарству 23-24. април 2019. Суботица, СРБИЈА

For design value of load bearing capacity of the fastener per shear plane in double shear steel-to-timber connection, where both thick steel plates are outward (figure 5h,j) loaded perpendicular in relation to axe direction of the fastener, it is necessary to take the lowest value calculated from fallowing expressions:

$$
R_{d}=\min \left\{\begin{array}{l}
0,5 f_{h, 2, d} t_{2} d \\
1,1 \sqrt{2 M_{y, d} f_{h, 1, d} d}
\end{array}\right.
$$

\section{ANALYSIS OF SOME EXAMPLES OF BUILDINGS WITH OPTIMALLY DESIGNED CONNECTIONS OF TIMBER STRUCTURAL ELEMENTS}

Figure 5, shows the 3D model of the object (the object "A"), which is currently in the execution phase and whose construction is in everything from glued laminated timber (GL). The object is of a specific form, with columns of different heights in different construction directions and roof beams of an asymmetric tappered form with variable geometry due to the variables of their spans. The beams are in the static sense of the simple beam and with spans from $18-22,0 \mathrm{~m}$. Columns are spaced and have a complex cross-section. Timber structure must also carry two industrial crane with spans of $18 \mathrm{~m}$ and $22 \mathrm{~m}$ and carrying capacity up to 5 tons. The length of the building is $20-24 \mathrm{~m}$, and the width is $50 \mathrm{~m}$. The secondary roof structure is of the dimensions of the cross-section of the rafters, and they are, in a static sense, simple beams, but in certain parts, the cantilever beams.

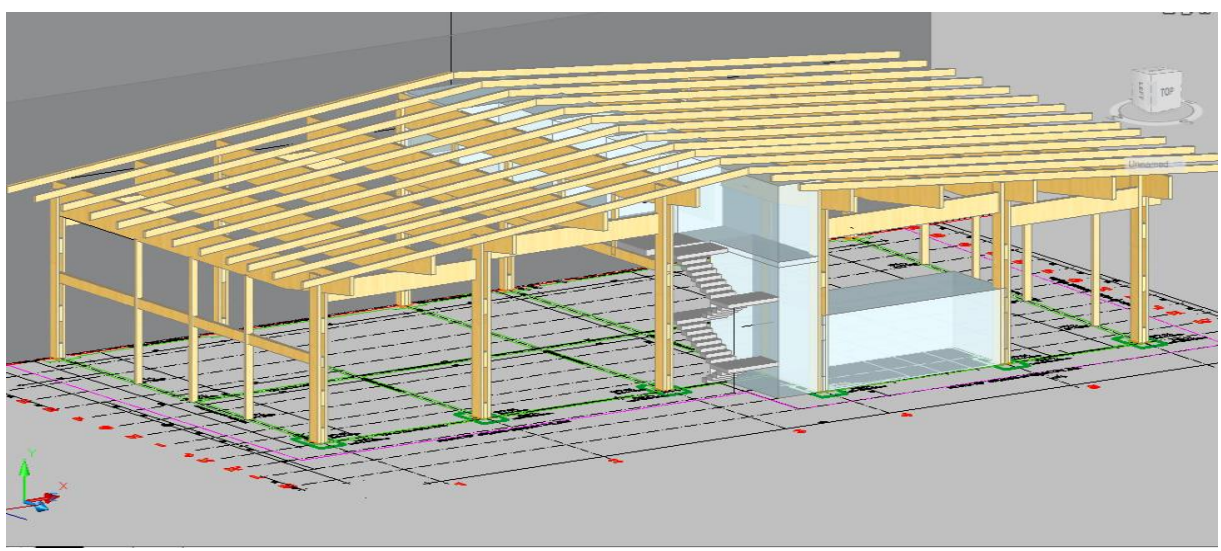

Figure 5. 3D model of timber structure (building ,,A')

In Figures $6 ., 7 \mathrm{a}, \mathrm{b}, \mathrm{c}, \mathrm{d}$, the complexity of the connections between the spaced columns, the roof beams and the second-row roof beams are crossed in certain areas of the construction of the "A" object. The usual solutions involve the application of steel striped profiles and connecting fasteners. 
Contemporary achievements in civil engineering 23-24. April 2019. Subotica, SERBIA

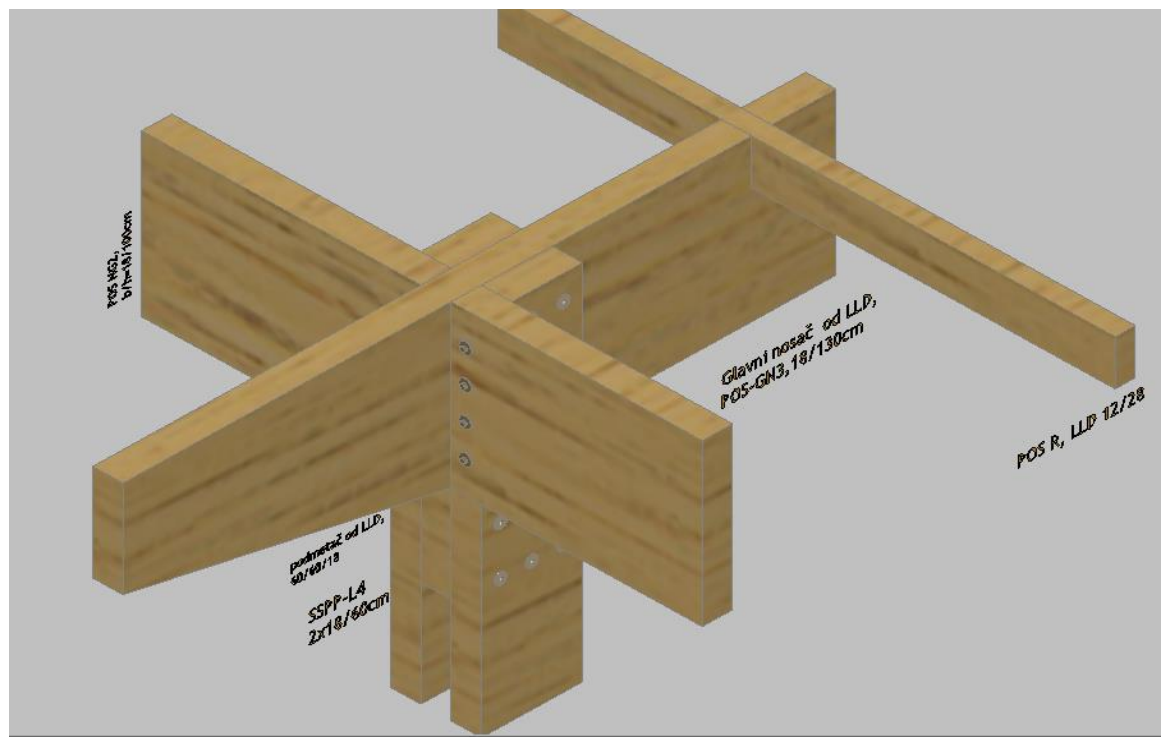

Figure 6. 3D model of complex connection of structural timber elementsConnection $1(\mathrm{Cl})$
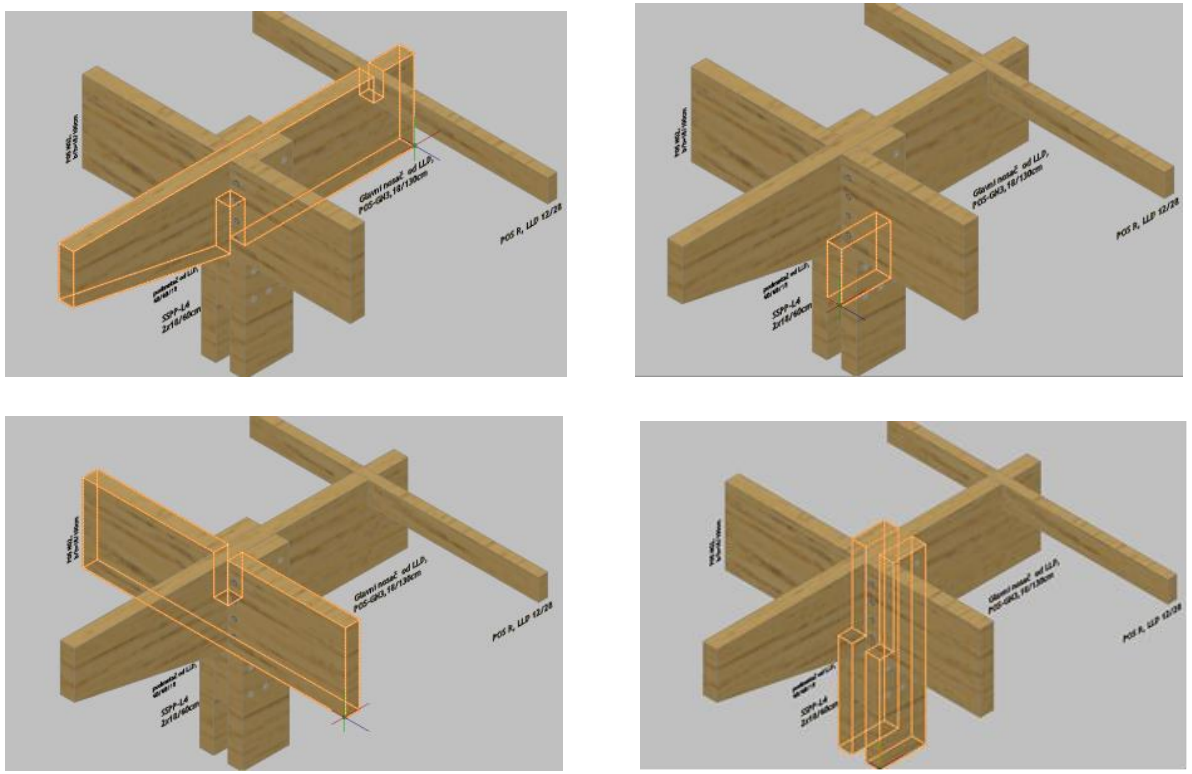

Figure 7a,b,c,d. Decomposition of complex connection of structural timber elements

Figure 9. shows a very practical way of connecting continual rafters and main roof beam of industrial hall- building „B". In the upper, pressed zone of the roof beam, notches of the cross-sectional dimensions of the rafters are created, the rafters are embedded in these notches and attached with two self-embedded screws of a certain length. In this 
Савремена достигнућа у грађевинарству 23-24. април 2019. Суботица, СРБИЈА

way, a safe connection of the main and secondary roof structural elements is obtained without the use of standard steel fittings, steel "slippers". In this way, it saves the materials in the time of construction. When creating such connections, if the height of the main roof beam is optimal, the beam in which the notches are made, it is necessary to check the stress state of the compression perpendicular to the grain in the contact of the lateral sides of the rafter and the vertical sides of the notch. In certain extreme calculating analyses, this method can also be considered as a process of timber coupling with timber.

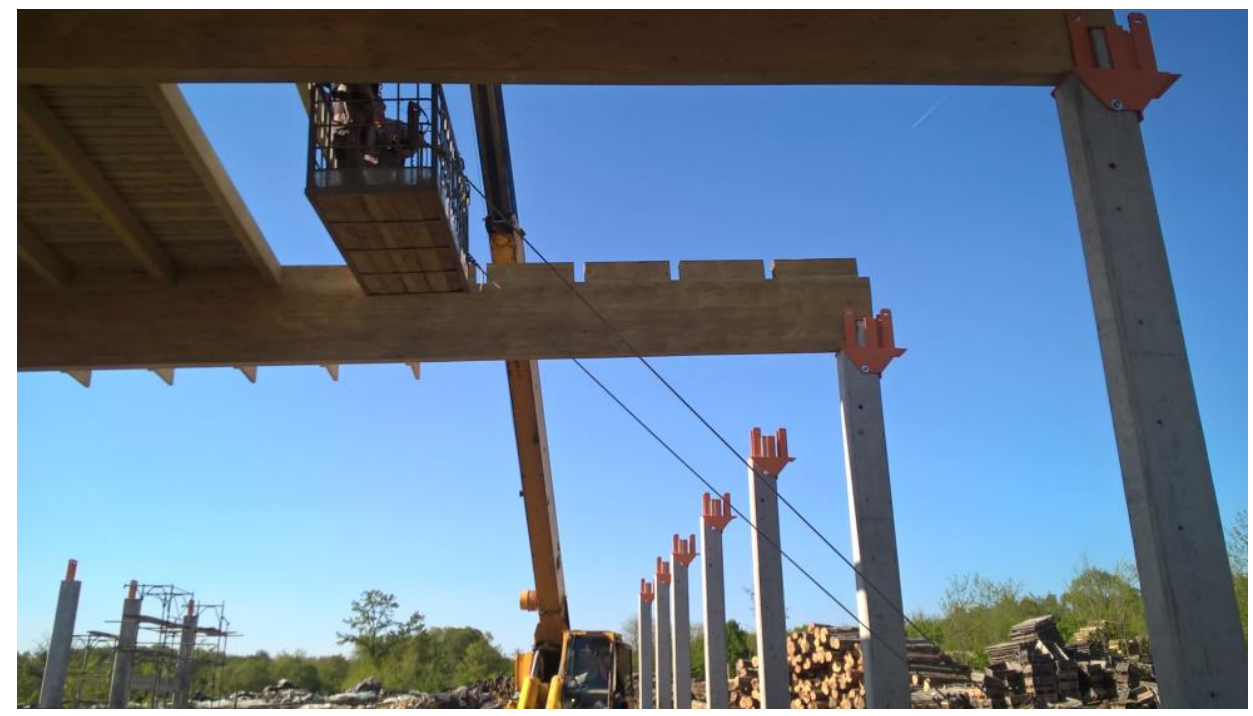

Figure 8. Erection of timber structures of industrial hall „,B”
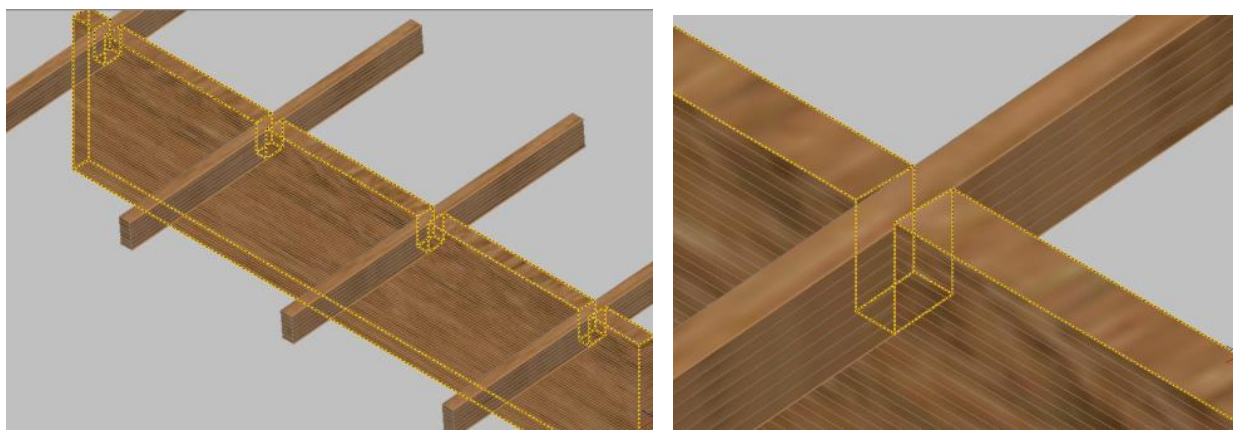

Figure 9. Connection of main roof timber beam and rafters- Connection 2 (C2)

The connection of the upper ends of the calcareous columns and roof beams can be solved simply by the procedure shown in Figure 7. By examining the geometry of the elements and their fitting, which takes into account the installation of the facade lining, in accordance with the results of the static-dynamic analysis, an optimal solution of the connection of such elements without the use of a steel fitting is achieved. 


\section{Contemporary achievements in civil engineering 23-24. April 2019. Subotica, SERBIA}
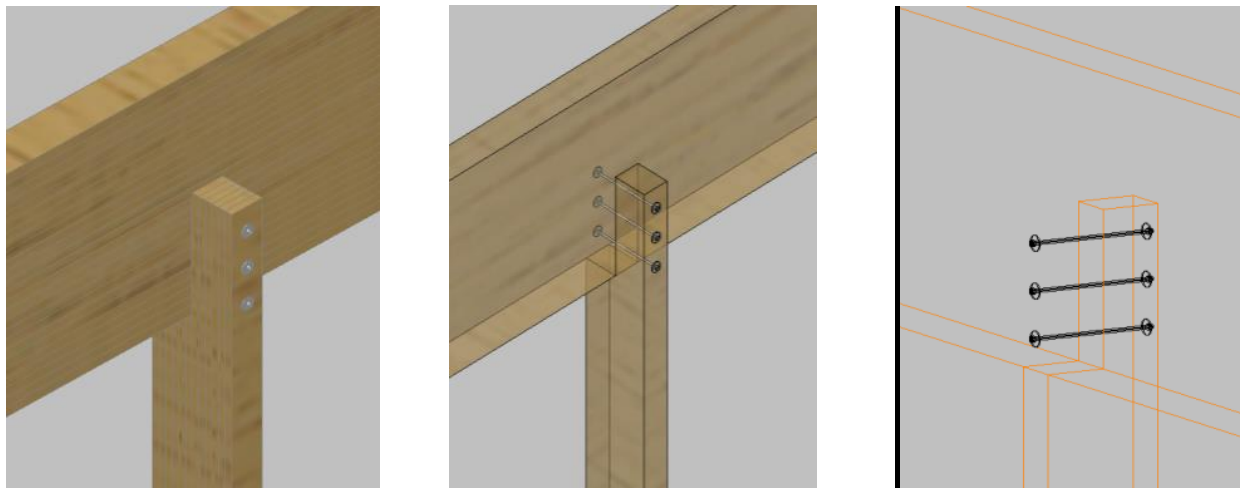

Figure 10. Connection of main roof timber beam and rafters-Connection 3(C3)

The following table shows the comparative cost of classic (connections made by steel profiled elements) and design and construction enhanced connections of the main and secondary carriers of the roof structure of the building "B" (details of C2 and C3) and the connections marked with the code $\mathrm{C} 1$ characteristic of the structure of the building ,A ".

\begin{tabular}{|l|l|l|l|l|l|l|}
\hline Details & \multicolumn{2}{|c|}{ C1 } & \multicolumn{2}{c|}{ C2 } & \multicolumn{2}{c|}{ C3 } \\
\hline & $\begin{array}{l}\text { with steel } \\
\text { elements }\end{array}$ & $\begin{array}{l}\text { with } \\
\text { fasteners, } \\
\text { only }\end{array}$ & $\begin{array}{l}\text { with steel } \\
\text { elements }\end{array}$ & $\begin{array}{l}\text { with } \\
\text { fasteners, } \\
\text { only }\end{array}$ & $\begin{array}{l}\text { with } \\
\text { steel } \\
\text { elements }\end{array}$ & $\begin{array}{l}\text { with } \\
\text { fasteners, } \\
\text { only }\end{array}$ \\
\hline $\begin{array}{l}\text { Building } \\
, \text { A“ }\end{array}$ & 4800,00 & 1400,00 & 3000,00 & 100,00 & 480,00 & 150,00 \\
\hline $\begin{array}{l}\text { Building } \\
\text {,B“ }\end{array}$ & - & - & 3000,00 & 100,00 & 480,00 & 150,00 \\
\hline
\end{tabular}

\section{CONCLUSION}

This paper deals with very important practical facts that we need for optimal calculation and projecting connections between structural timber elements with a tendency "how to reduce steel in timber structures?" In calculating observations a new fashioned designed concept, Eurocode 5, based on the ultimate limit states and serviceability limit states, here is applied. In optimally designed and well determined timber constructions, dedication to the design and creation of details of structural elements is unavoidable. The significant differences in the costs of building objects "A" and "B" based on the displayed solutions of connections lead to the correctness of this approach.

\section{REFERENCES}

[1] H. J. Blaß, A. Bienhaus, V. Krämer: Effective Bending capacity of dowel-type fasteners" CIB-W18/33-7-5, Working Commission W18-Timber Structures, Meeting Thirty-three, Delft, Netherlands, August 2000. 
[2] Dietsch P.: The practical design of dowel-type connections in timber engineering $\mathrm{p}$. structures according to EC5, Proceedings of the Conference of COST Action FP1402, Graz University of Technology, Institute of Timber Engineering and Wood Technology, Graz, Austria, 2017, pp 6-15.

[3] Stojic D.:"Innovations in the design of timber structures", Facta Universitatis: Architecture and Civil Engineering Vol. 2, No 1, 1999. Pages,77-83.

[4] Stojic D., Cvetkovic R.: Design of load-bearing capacity of typical fasteners used in composite timber-concrete connections, Monografija:Theoretical and Experimental Research of Elasto-Plastic Behaviour of Engineering Structures 2006, ISBN 8680295-71-X, стр. 201-215.

[5] Stojić D., Cvetković R.: Nosivost i pomerljivost spojnih sredstava u savremenim drvenim konstrukcijama, Zbornik radova Građevinsko-arhitektonskog fakulteta u Nišu, br. 20, 2004, str. 77-84.

[6] Stojić D., Cvetković R.: Novi koncept proračuna veza u savremenim drvenim konstrukcijama, Zbornik radova Simpozijuma Jugoslovenskog društva građevinskih konstruktera, Vrnjačka Banja 29.9-1.10, 2004. Knjiga 2, str. 162-168.

[7] Dragoslav Stojić D., Cvetković R.:Spojna sredstva i tehnike spajanja u savremenim drvenim konstrukcijama, INDIS, Novi Sad 2003.

[8] Cvetković R.: Behaviour of Composite Timber-Concrete Structures with Bending Actions", Master thesis, Department of Reinforced Concrete and Prestressed Concrete Structures, Ruhr University Bochum, Germany, 2002.

[9] Stevanovic B.: Analysis of Composite Timber-Concrete Structures, Doctoral thesis, Faculty of Civil Engineering, Belgrade, 2003;

[10] Deutschen Institut für Normung (DIN). „E DIN 1052: Entwurf, Berechnung und Bemesung von Holzbauwerken“, Juli 2000;

[11]ENV 1995-1-1.Eurocode 5: Design of timber structures. Part 1.1: General rules and rules for building. European Committee for Standardisation.1993;

[12] ENV 1995-1-1.Eurocode 5: Design of timber structures. Part 2: Bridges;

[13] Main project of timber structures of industrial hall in Pojate , Kruševac, 2016.

[14] Main project of timber structures of warehouse in Pojate, Kruševac, 2017.

\section{UNAPREĐENJE VEZA U DRVENIM KONSTRUKCIJAMA U TEORIJI I PRAKSI}

Rezime:Veze između drvenih konstrukcijskih elemenata ostvaruju se, najčešće, različitim čeličnim spojnim sredstvima koja se ugrađuju u kombinaciji sa posebno oblikovanim, čeličnim elementima, u skladu sa određenim teorijskim postavkama i proračunima. Kod konstrukcija od monolitnog drveta (MD) ili lepljenog lameliranog drveta (LLD), velikih raspona, prisutan je veliki utrošak čelika za izradu veza elemenata primarne i sekundarne konstrukcije. $U$ ovom radu je dat kratak pregled razvoja i unapređenja savremenih modela $i$ postupaka proračuna veza u drvenim konstrukcijama, kroz primere originalnih projektantskih rešenja kojim je dostignuta ušteda spojnih sredstava u odnosu na klasičan način oblikovanja veza između drvenih elemenata. Ova rešenja praćena su potrebom za visokim kvalitetom izrade nosača od LLD-a i preciznom završnom obradom.

Ključne reči: drvo, konstrukcijski detalji, veze, spojna sredstva, razvoj. 